\title{
Cooperative Learning in VR Environment
}

\section{Viktória Kövecses-Gősi}

Apáczai Csere János Faculty, Széchenyi István University, Liszt Ferenc utca 42, H-9022 Győr, Hungary, gosi.viktoria@sze.hu

\begin{abstract}
Nowadays it is increasingly visible that a change in the approach is needed in the field of education, thus we should move from "traditional" educational methods towards experience-oriented and cooperative teamwork-based education which considers the characteristics of the digital generation. After the brief demonstration of the methodological characteristics and the principles of digital culture, the present study aims to introduce how a lesson built on the improvement of different intelligence levels through cooperative techniques can be implemented with the help of virtual space, what opportunities are provided by the MaxWhere program for planning and organising teamwork and for supporting learning.
\end{abstract}

Keywords: cooperative learning; VR learning environment; MaxWhere; teaching methodology; digital culture; the improvement of intelligence areas; formative assessment; interactive learning-teaching

"Kids naturally know how to be in the state of flow. They learn fast because they find learning exciting. No money has to be paid for an infant for learning how to talk or walk, as he has a natural urge to improve his knowledge. However, when we close them into the school, where they have to sit and listen, it is not natural to them. This is a misunderstanding of the adult-world about how we learn."

(Mihály Csíkszentmihályi)

\section{Introduction}

Whatever level of the school system we look at, we can see that professionals working in education report the same problems everywhere. The lack of interest and motivation, the lack of perspectives and aims, inattentiveness, attention disorders, a fall in the quality of communication and human relations, the low level of emotional intelligence, or the seemingly higher rate of learning- and conduct disorders make pedagogues think in every area. Many do not find the way to the students, and instead of working together for the common good by cooperation, they run away in opposite directions and criticise negatively the youth whose future is dependent on us as well. 
All these symptoms show that a change in approach is needed in the field of education, thus we should move from "traditional" educational methods towards experience-oriented and cooperative teamwork-based education which considers the characteristics of the digital generation. After the brief demonstration of the methodological characteristics and the principles of a digital culture, the present study aims to introduce how a lesson built on the improvement of different intelligence levels through cooperative techniques can be implemented with the help of virtual space. Also, we present, what opportunities are provided by the MaxWhere program for planning and organising teamwork and for supporting learning.

\section{Cultures, Differences between Generations, Problem Areas}

There have always been generational differences and conflicts; however, today it has intensified and besides the generational differences, cultural differences have evolved as well. Those parents who raise children nowadays as well as the older adults grew up in the culture of literacy; however, the children they raise and teach are the natives of the digital culture. "Today a baby boomer-aged teacher or parent (who is either close to retirement or already retired) has to bridge much more distance than a younger person of Generation Y (in their thirties) has to. It is not only about the usual generational differences, but also about how to handle the changes caused by information age and technological developments and merging them harmonically in both home training and education." (Tari A. 2011: 17)

In recent years we have seen the spread of those summaries and the related psychological descriptions that reveal the typical characteristics of the different generations. Table 1 provides a brief and schematic overview of these generations and their essential characteristics.

Table 1

The different generations and their typical characteristics

\begin{tabular}{|l|l|}
\hline \multicolumn{1}{|c|}{$\begin{array}{c}\text { Generations } \\
\text { (W. Strauss, N. Howe 1991) }\end{array}$} & \multicolumn{1}{c|}{$\begin{array}{c}\text { Their typical characteristics } \\
\text { (Tari A. 2010, 2011, 2013, 2015) }\end{array}$} \\
\hline $\begin{array}{l}\text { Baby boom generation: } \\
\text { 1946-1964 }\end{array}$ & $\begin{array}{l}\text { "A descent fellow has one workplace." } \\
\text { They were eager to be an adult. } \\
\text { They did not use infocommunication tools. } \\
\text { They were compelled to express their feelings verbally. } \\
\text { They have old attitude while they nurture/teach/look after } \\
\text { the new digital generation. } \\
\text { They try to pass value in a world where values have been } \\
\text { transformed. } \\
\text { Lack of parental control over the child's internet activity. }\end{array}$ \\
\hline
\end{tabular}




\begin{tabular}{|c|c|}
\hline & $\begin{array}{l}\text { The family communication system does not sufficiently } \\
\text { include the educational attitudes needed in information } \\
\text { age. } \\
\text { They were raised in an authoritarian system. }\end{array}$ \\
\hline Generation Y: 1980-1994 & $\begin{array}{l}\text { They are special; at least they may feel that, because they } \\
\text { were cared for a lot in their childhood, much more than } \\
\text { any other generation. } \\
\text { Helicopter parents are circling over the heads of many, } \\
\text { even in their twenties. They cannot detach. } \\
\text { They like working in teams. } \\
\text { They are ambitious, highly-motivated and rational. } \\
\text { A high pressure is put on them as they start their adult life } \\
\text { in a more insecure economic environment than their } \\
\text { parents did. } \\
\text { For them computer world and Internet are as natural as } \\
\text { breathing. }\end{array}$ \\
\hline $\begin{array}{l}\text { Generation Z: 1995-2009 } \\
\text { (Digital native) }\end{array}$ & $\begin{array}{l}\text { They are born into the smallest family. } \\
\text { They are growing faster and faster. } \\
\text { They are raised by the oldest mothers so far. } \\
\text { They are the most educated. } \\
\text { They show mosaic maturity. } \\
\text { They do not have an easy childhood. They understand a } \\
\text { lot, but are able to process a few. } \\
\text { More and more aggressive effects affect them. } \\
\text { They are small consumers in the consumer society. } \\
\text { They face informational surfeit. } \\
\text { They are constantly in touch.(online) }\end{array}$ \\
\hline Alpha generation: 2010- & $\begin{array}{l}\text { They are typically raised by parents of Generation Y. } \\
\text { Due to the advances in technology, it is more and more } \\
\text { difficult for these parents to decide what is good for the } \\
\text { child and what is early for them. } \\
\text { Digitalisation has become an integral part of everyday } \\
\text { life; touch screens are constantly present at family } \\
\text { lunches, at bedtime, and on road trips. } \\
\text { There is no established practice or norms of using the } \\
\text { devices; it varies from family to family what is } \\
\text { permissible and acceptable. }\end{array}$ \\
\hline
\end{tabular}

By reading the writings of Annamária Tari, many questions may arise. How can we help the school and out-of-school learning activities of the different generations, what effective methods and tool system can we use in education, and what is the most important, which methods support the putting forth of the personality of the youth who are isolated from each other and only keep in touch virtually with each other, as well as the enhancement of their emotional intelligence, and the improvement of their personal, live communication culture? 
In an age when we gradually move from the culture of literacy towards a digital culture, several other sources of tension appear. (Gyarmathy, 2012) In case of digital natives, mainly visual experiences dominate instead of experiences through motion and perception. Instead of active activity, the operation of machines is in the centre. They very often have ready-made pictures instead of utilizing their imagination, which impedes the improvement of their creativity. Instead of linguistic expression, visual expression moves to the front. The extent of attention does not function as it did before. The nervous system does not learn the delicate comparisons, so the harmonic cooperation between the two cerebral hemispheres is in danger too. (Gyarmathy 2012) "The school traditionally favours and thus develops left-brained function. School processes lack the understanding of relationships, creative thinking, intuition, and art, although the teaching of logical, analytic, and scientific thinking is at a high-level." (Gyarmathy 2012: 53) According to Gyarmathy, the school prepares students for linear, scientific thinking, and not for life. which is diverse, full of various opportunities, and cannot be restricted to categorical thinking. The right cerebral hemisphere adds everything that is needed for problem-solving thinking of left-brained function.

The Digital culture is built upon one-sided right-brained function; however, education is unequivocally built on a left-brained one. (Gyarmathy 2012: 54) It is a question how these two so different systems can make contact with each other. They can, but only if we organise and support the learning process by giving role to methods, procedures, and forms of activities which aim at the joint activating of the two cerebral hemispheres. A basic requirement of effective learning is to harmonise the two different cultures as well as the function of the two cerebral hemispheres.

\subsection{In the Digital Age the Main Pillars of Education Consist of the Following Factors}

- Adaptive, differentiated instruction

- Education designed based on the theory of multiple intelligences

- The improvement of emotional intelligence

- Formative assessment

- $\quad$ Learning to learn

- Cooperative learning

- Project planning

- Strategic games

- Motion, music, rhythm, beat, balance exercises

- Art

I do not plan to introduce all these fields in detail in the present paper: however, briefly summarise the essential definitions and the methodological principles from the viewpoint of the topic. Then, through a practical example demonstrate the implementation options of a lesson designed based on cooperative learning and the theory of multiple intelligences with the help of VR learning environment. 


\section{The necessity of adaptive, differentiated instruction}

The pupil is an active participant of the education process and not a sufferer of it, regardless of their age. The (adaptive) education environment which adapts to the pupil's personality assumes the diverse ways to success, the wide range of eligible aims, and not one of those ways to success is more valuable than the other. (R. Glaser) Differentiation that considers individual characteristics and unified teaching directed at the knowledge of individual characteristics together compose adaptive instruction. (Nádasi M. 2001: 28-40)

In adaptive learning management, which adapts to the pupils' personality in a differentiated way, a major role is given to: activating methods, the diversely used learning management ways, and to the tool system it requires. In case of adaptive learning management it is important to take into consideration that pupils engage in diverse learning and experience-gaining ways along various fields of interest with different motivations.

\section{Education designed based on the theory of multiple intelligences}

Howard Gardner, who elaborated the theory of multiple intelligences, suggests that we should know as much as we can about kids instead of trying to fit them into the eye of the same needle. Having analysed the cognitive abilities of different groups of people, Gardner found that intelligence focuses on the different areas of the brain, and these areas are connected to each other, one area builds on the other, but in case of necessity they can function independently as well, and among appropriate circumstances these areas can be improved. As a result of his research he defined eight intelligence areas, the improvement of which is indispensable in the process of education. (Kristen Nicholson - Nelson 2007: 1112) Table 2 illustrates the intelligence areas and their typical characteristics which may serve as bases for planning.

Table 2

The characteristics of the areas of multiple intelligences

(Diane Heacox 2006), (Kristen - Nelson - Nicholson: 2007)

\begin{tabular}{|c|c|c|}
\hline $\begin{array}{c}\text { Intelligence } \\
\text { area }\end{array}$ & $\begin{array}{l}\text { Strengths, typical } \\
\text { characteristics }\end{array}$ & $\begin{array}{l}\text { Pupils learn the most through } \\
\text { these }\end{array}$ \\
\hline $\begin{array}{l}\begin{array}{l}\text { Verbal } \\
\text { linguistic }\end{array} \\
\text { Tell it! }\end{array}$ & $\begin{array}{l}\text { A facility with words and } \\
\text { linguistic delicacies, sensitivity } \\
\text { to word order and the rhythm of } \\
\text { words. } \\
\text { Keywords: Reading, writing, } \\
\text { storytelling, memorizing data, } \\
\text { verbal thinking }\end{array}$ & $\begin{array}{l}\text { Reading, listening and seeing } \\
\text { words, talking, writing, discussion } \\
\text { and debate }\end{array}$ \\
\hline $\begin{array}{l}\text { Mathematical } \\
\text { - logical } \\
\text { Count it! }\end{array}$ & $\begin{array}{l}\text { The ability to understand abstract } \\
\text { systems and relationships, ability } \\
\text { to inductive and deductive } \\
\text { reasoning. }\end{array}$ & $\begin{array}{l}\text { Working with schemes and } \\
\text { relations systems, systematisation, } \\
\text { categorisation, working with } \\
\text { abstractions }\end{array}$ \\
\hline
\end{tabular}




\begin{tabular}{|c|c|c|}
\hline & 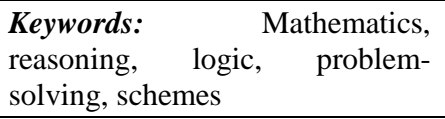 & \\
\hline $\begin{array}{l}\text { Visual - } \\
\text { spatial } \\
\text { Illustrate it! }\end{array}$ & $\begin{array}{l}\text { The ability to create visual - } \\
\text { spatial forms about the world to } \\
\text { transform them in thought or in } \\
\text { reality. } \\
\begin{array}{l}\text { Keywords: Reading, maps, } \\
\text { figures, mazes, puzzles, } \\
\text { imagination of things, } \\
\text { visualisation }\end{array}\end{array}$ & $\begin{array}{l}\text { Working with pictures and colours, } \\
\text { visualisation, the use of internal } \\
\text { vision, drawing }\end{array}$ \\
\hline $\begin{array}{l}\begin{array}{l}\text { Bodily } \\
\text { kinesthetic }\end{array} \\
\text { Move! }\end{array}$ & $\begin{array}{l}\text { Pupils having developed bodily - } \\
\text { kinesthetic intelligence prefer } \\
\text { expressing themselves in motion. } \\
\text { Keywords: Athletics, dance, } \\
\text { acting, handicraft, the use of } \\
\text { tools }\end{array}$ & $\begin{array}{l}\text { Taction, motion, the knowledge is } \\
\text { processed through physical } \\
\text { sensations }\end{array}$ \\
\hline $\begin{array}{l}\text { Musical } \\
\text { Hum it! }\end{array}$ & $\begin{array}{l}\text { Sensitivity to pitch, tone and the } \\
\text { rhythms of notes, and sensitivity } \\
\text { to the emotional load of these } \\
\text { elements of music. } \\
\text { Keywords: Singing, noting notes, } \\
\text { recalling melodies, rhythms }\end{array}$ & $\begin{array}{l}\text { Rhythm, melody, singing, listening } \\
\text { to music }\end{array}$ \\
\hline $\begin{array}{l}\text { Interpersonal } \\
\text { Lead! }\end{array}$ & $\begin{array}{l}\text { Effective cooperation, the ability } \\
\text { to strive for understanding the } \\
\text { others' aims, motivations, and } \\
\text { orientations. } \\
\text { Keywords: Understanding } \\
\text { people, leadership, organisation, } \\
\text { communication, conflict } \\
\text { management }\end{array}$ & $\begin{array}{lrr}\begin{array}{l}\text { Discussion } \\
\text { comparison, } \\
\text { cooperation }\end{array} & \begin{array}{r}\text { with } \\
\text { linking, }\end{array} & \begin{array}{r}\text { others, } \\
\text { interview, }\end{array}\end{array}$ \\
\hline $\begin{array}{l}\text { Intrapersonal } \\
\text { Reflect! }\end{array}$ & $\begin{array}{l}\text { The ability to understand their } \\
\text { own emotions, aims, and } \\
\text { intentions. Pupils having } \\
\text { developed intrapersonal } \\
\text { intelligence have strong self- } \\
\text { consciousness, are self-confident, } \\
\text { and like working alone. They } \\
\text { instinctively measure well their } \\
\text { strengths and abilities. } \\
\text { Keywords: Self-knowledge, the } \\
\text { knowledge of their own strengths } \\
\text { and weaknesses, defining aims, } \\
\text { reflection }\end{array}$ & $\begin{array}{l}\text { Working alone, performing } \\
\text { individual-rate projects, enough } \\
\text { space, reflection }\end{array}$ \\
\hline $\begin{array}{l}\text { Naturalistic } \\
\text { Explore! }\end{array}$ & $\begin{array}{l}\text { The ability with which natural } \\
\text { world can be seen from a wider } \\
\text { perspective which includes the } \\
\text { understanding of the } \\
\text { interrelatedness between nature }\end{array}$ & $\begin{array}{l}\text { Work in nature, the exploration of } \\
\text { wildlife, learning about plants and } \\
\text { natural phenomena. }\end{array}$ \\
\hline
\end{tabular}




\begin{tabular}{|c|c|}
\hline & $\begin{array}{l}\text { and civilisation, of the symbiotic } \\
\text { relationships in nature, and of the } \\
\text { cycle of life. } \\
\text { Keywords: Understanding nature, } \\
\text { distinguishing things, the } \\
\text { recognition of flora and fauna. }\end{array}$ \\
\hline
\end{tabular}

If we design the lessons, activities by considering intelligence areas, inter alia differentiation can be more effective as well. Every pupil/student has the characteristics which enable the putting forth of each area, and by this, other areas can be improved more effectively. Lessons designed based on this approach exceedingly help the harmonization of the two cerebral hemispheres' functions. This theory is applicable to any age group; either we deal with pupils from lower school in the forest school or with those adult teacher candidates who will teach children in public institutions.

\section{Formative assessment}

"If you treat an individual as he is, he will remain how he is. But if you treat him as if he were what he ought to be and could be, he will become what he ought to be and could be."

(Goethe)

"It means the frequent and interactive assessment of the pupils' improvement and knowledge, and its aim is to determine learning objectives and to accommodate teaching to these." (OECD CERI, 2005.) (Lénárd S. - Rapos N. 2009:20) In the course of this, assessment constantly follows and supports the learning process, which makes it possible to design the processes and possibilities of progress, the forms of differentiation as well as its tool system adapted to the pupils. In this assessment process the pupil is also an active participant as a result of which selfassessment can be improved efficiently and the development of reflective approach is supported. Assessment in this case does not only mean the reproductive testing of knowledge, but it also enables to get acquainted with changes in competences to be developed.

"Formative assessment is a system-level process during which the emotional development of pupils is of importance as well besides the diversity of assessment tools; and besides consciousness, self-assessment, empathy, cooperation, and flexibility are also important factors regarding compliance in life. When designing the lesson, not only the necessary sectioning of the curriculum must be made, but the activities necessary for the development of the given skills must be determined too besides the applicable development assessment tools and methods. It may help learning if teachers let the pupils in on the processes designed by them, thus pupils may see the purpose of the lessons in a clearer way."(Cseh Á. G.)

Formative assessment is more than diagnostic assessment because it mainly follows a preventive approach. It states the pupils' development and interprets 
their learning needs. Its quintessence is actually the support of: development, the enhancement and the support of self-image, metacognition, and of selfassessment. However, in order that assessment can fulfil its developmental function, we have to know how the pupils can be motivated well, which learning strategy characterises them, which learning-methodological recommendations are useful for them, how their interest can be broadened, whether they can learn in groups by cooperating, and which thinking functions are worth strengthening. (Lénárd, Rapos, 2009) During formative assessment we can use various assessment tools like key cards, learning diaries, individual learning plans, Tcards, self-assessment, peer-assessment or team- assessment sheets or learning portfolios of different types. Portfolio is "the collection of such documents which shed light on someone's knowledge, skills, and attitude gained in a given field". (Bird 1990, cited by Falus-Kimmel 2008:196) "Is a targeted collection of the pupil's work, which introduces the pupil's efforts, development and results in one or more fields. The pupil must take part in compiling the content as the collection must include the criteria used for choosing among the documents as well as the self-reflections of the pupil." (Northwest Evaluation Association, 1990, cited by Falus-Kimmel 2008:196) Basically there are two main reasons for making a portfolio: it may serve the assessment, as well as, the facilitation of learning. With the help of the portfolio we can document the whole learning process. Its use enables constant assessment, feedback, and self-evaluation. It helps the development of reflective thinking, the cognition and the understanding of metacognitive knowledge and the knowledge we have about our own process of thinking and learning. When compiling the portfolio it is very important that pupils should get appropriate information about it as a form of assessment as well as about its compilation and the evaluation criteria. The literature distinguishes different portfolios based on what they focus on, i.e. what is the aim of collecting pupils' work. Among the many subtle types, the most common in education are as follows. Development portfolio, illustrates the progress of the pupil's learning by collecting documents from as many fields and as wide activities as possible. Process portfolio, is similar to the previous one, but here the progress process of only one determined field is in the centre, and the small steps, elements related to this are also included. Best works portfolio, only includes the most important works chosen by the pupil. Pupils collect these works from those which are considered to best represent themselves and theirs results. Learning aims portfolio, contains those aims which the pupil wants to reach during a given learning process as well as those exact examples by which it can be verified that the pupil reached these aims. Of course, there are several other forms of portfolio in practice. Various methods are known for collecting, systematising and storing pupils' work. Using a portfolio enables the pupil to be an active participant of their own learning process. The assessment process is including digital tools in more and more places. (Rapos-Lénárd 2006: 26.) 


\section{Cooperative learning}

Openness towards cooperativity, the knowledge, the routines, the skills, the competences, the abilities needed for teamwork, and last but not least, the attitudes needed for these are basic criteria in the workplace of the $21^{\text {st }}$ Century. However, in many cases we experience that we lack these competence elements and selfishness, self-reliance which does not take into account the interests of others, self-fulfilment, and rivalry are in the centre. Although young people behind their computers and smart phones virtually form a community and "cooperate", it is more difficult that real cooperation with shared responsibilities and the pursuit of common success should become useful and successful practice within the frames of the classroom. Slavin, Kagan, Johnson and their research groups proved that cooperative learning management has a positive effect on the acceptance and tolerance of ethnic differences.

"As a result of cooperative learning, the relationship between pupils belonging to different ethnic groups got better compared to the control group, moreover cooperative learning resulted in enhanced social development and mending social relationships." (S. Kagan 2001. 3:2) It is also a significant result that the two grades difference between the learning outcomes of American and Afro-American pupils disappeared by cooperative learning management. Afro-American pupils overtook their arrears of work. Unfortunately, today's school prioritises competitive methods in which rivalry is in the centre. The question may arise how we should prepare the growing generation for cooperation if it is not emphasised enough in the school. How can pupils work on the realisation of common problems and innovations as adults; how can they be tolerant and acceptable with others if during learning in the school they do not meet such methods and strategies which improve those basic skills, abilities and competences that are needed for that cooperation?

According to Green, cooperative learning is not only a teaching method, but an attitude of life which prioritises cooperation based on mutual respect and the individual performance of each community member. A precondition of it is the consensus, which is a result of the cooperation among the community members. Based on previous experience it can be said that those pupils who are able to use cooperative learning are also able to adapt this cooperative approach to other areas of life. (Óhidy 2011)

According to the definition of Beáta Kotschy Beáta, cooperative learning is "a small group activity based on the cooperation of participants, which may be organised to reach various aims, may help the pupils' improvement in learning, and may contribute to the evolvement of abilities and skills that are needed for cooperation as well as to the development of real self-evaluation and problemsolving thinking. It provides opportunity for practicing social behaviour forms, expressing own thoughts and emotions precisely and in a differentiated way, and for imbibing debate skills that take into account logical reasoning, concluding, and 
the emotions of others. Common goals, responsibility and sharing the results facilitate the evolvement of respect for others, helpfulness and a real selfimage.” (Kotschy Beáta, 1997: 277-278)

During cooperative learning pupils perform their learning activity in groups of 4 to 6 , where the formation of social competence also has an important role besides the improvement of intellectual abilities and knowledge transfer. Intra-group dependence, individual responsibility, and joint learning management within the group are the characteristics of cooperative teamwork. During the activities solving the task and the relationship among the group members are equally important. The teacher follows the work of the group with attention and in case of necessity interferes in a helping way. It is the task of the group to evaluate and reflect on the learning process. (Johnson - Johnson 1994) During cooperative learning it is of high importance that besides parallel simultaneous interactions we should divide the tasks among pupils so that positive dependency relationship could evolve among them in order that they could feel that their knowledge is built on each other as well. They all may contribute to successful task performance by their knowledge, motivation and skills. We can support it by appropriately distributing the roles and the responsibilities.

During the teaching of the digital generation we may successfully combine cooperative techniques and the development of different intelligence areas with digital technology, and thus we may make the teaching - learning process more interesting and more effective.

The lesson above took place among students of teacher-training who can study the so-called Cooperative learning subject in two hours of practice a week at the university. During the work built on cooperative learning with own experience, students imbibe the more theoretical parts of the curriculum with cooperative techniques.

This subject, which has been in practice for many years, is supported by VR learning environment in the $2^{\text {nd }}$ semester of the 2017/2018 academic year. When designing the teaching lesson I worked with the AMR model (ATTUNEMENT MEANING AWARENESS - REFLECTION), which "is a possible learning learning-supporting model in favour of critical thinking and interactive learning. Students have to get personal experience of what it means to meet the information, how they should elaborate it, and how they should make the information usable for themselves as well. They have to follow the systematic path of critical thinking and the rethinking of the analytical process. So that it could happen in the community of the students, the teacher has to provide the systematic- approached, but not evident framework of thinking and learning. Being systematic is important because in this way students are able to understand and apply this process consistently. On the other hand, this framework has to be evident so that students themselves could realise where they are in the process, and in this way they can control and manage it even if they study individually". (Bárdossy - Dudás Pethőné - Priskinné, 2002, 172-174) 
To organise the lesson and to synthesise the curriculum and the tasks, from the MaxWhere spaces I chose the $\mathrm{X}$ Podium which is apt for group work because it provides the placement of group-tailored tasks and teaching aids for four separate groups.

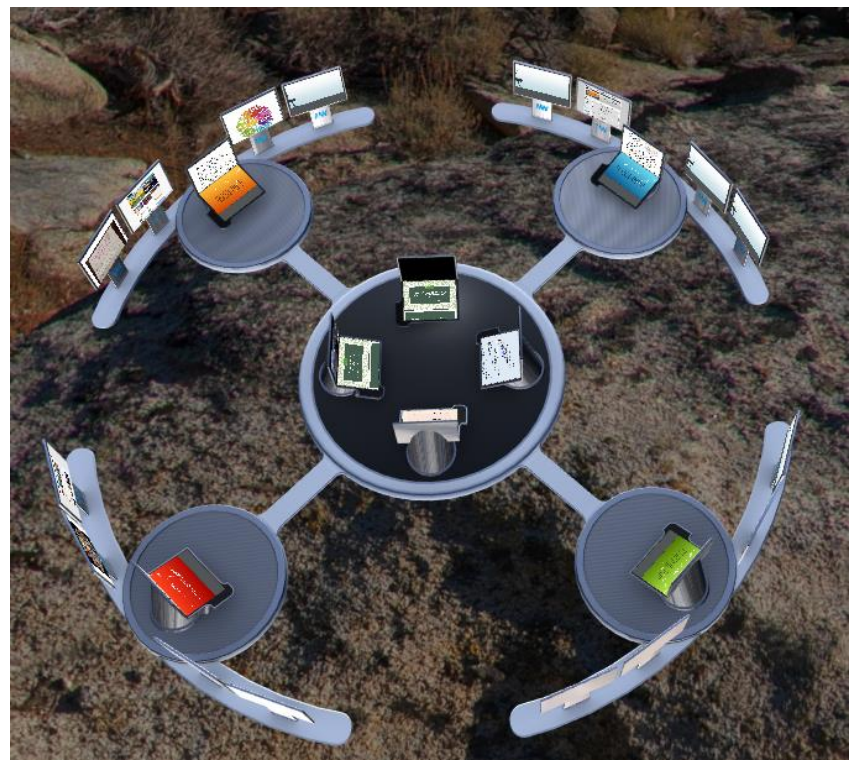

Figure 1

X-Podium

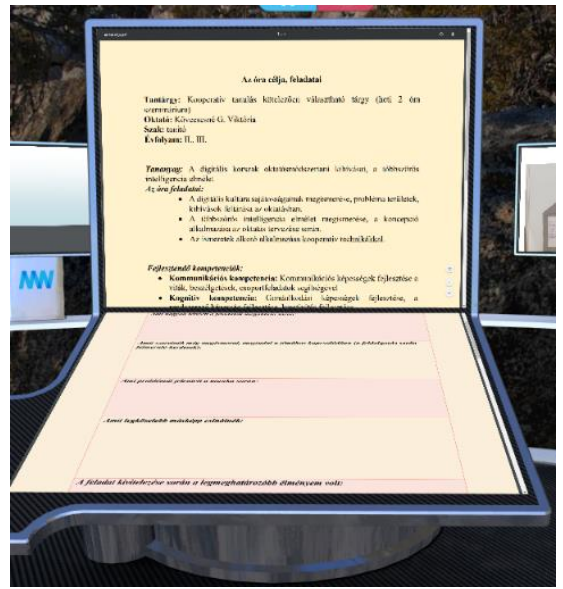

I equipped the space in a way that the middle part contains the tutorial presentations related to the lesson, the literature suggested and used for researching the topic, the objectives of the lesson, the evaluation criteria of the group work and of the individual work, and some videos related to the topic.

Figure 2

Self- and peer-assessment sheet, the objective of the lesson, the competences to be developed

\section{The outline of the teaching lesson:}

Subject: Cooperative learning ( 2 hours of seminar a week)

Class: II, III

Curriculum: The education methodological challenges of digital era, the theory of multiple intelligences 


\section{The tasks of the lesson:}

- Getting to know the characteristics of the digital era, revealing the problematic fields and the challenges in education.

- Getting to know the theory of multiple intelligences and the application of the conception during the design of the education.

- The creative application of knowledge by cooperative techniques.

Competences to be developed:

- Communication competence: Developing communication competences with the help of debates, discussions, and group tasks

- Cognitive competence: Developing reflective competences, systematising abilities and creativity

- Social competence: Developing cooperative cooperation, joint problemsolving, tolerance, and adaptive ability

- Personal competence: Developing self-knowledge, self-assessment, self-regulatory learning, and metacognition

Applied methods: discussion, demonstration, explanation, role play, techniques developing cooperative and critical thinking (tablecloth technique, literary groups, insert technique, exit cards)

\section{Learning management:}

frontal work, cooperative group work, individual work

\section{Tools:}

text parts, tools needed for group formation, templates, photocopied materials, VR

\section{The course of the lesson:}

\section{Attunement}

Group formation: (4 groups, each containing 4-6 students) it took place randomly with mosaic technique. Students took the pieces of four pictures out of an envelope. Those students whose pieces matched formed a group in the given lesson (the pictures were related to cooperative learning). As the aim of the subject is to get to know various techniques of group formation, group formation has taken place in more times at the beginning of the lesson during the semester, so that the same students have not worked together throughout the whole semester.

Exploring preliminary knowledge: With structured settlement (or tablecloth) technique: each group member wrote their own end of the sentence after a brief consideration, and then after individual work, group members agreed on their 
common opinion and wrote the group opinion into the middle of the figure. Groups then reported their common point of view.

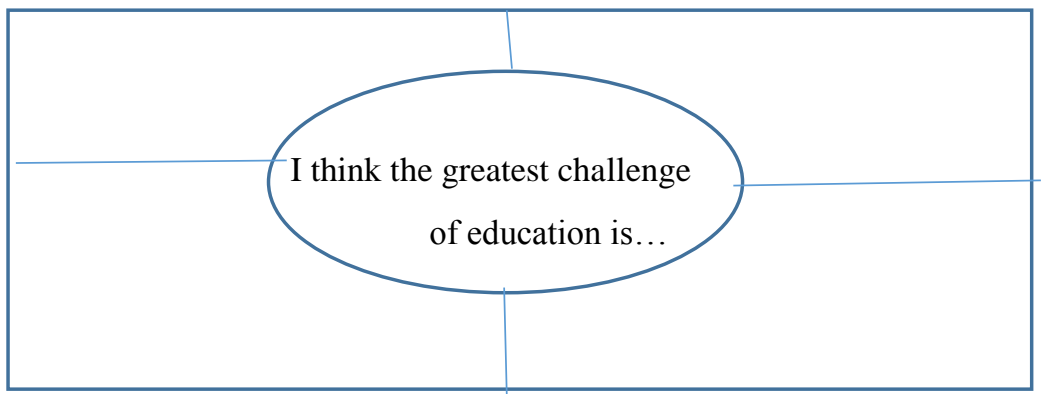

\section{Meaning creation}

Group members received two types of studies in the 3D space. One of them deals generally with the education methodological challenges of the digital era, while the other study introduces the theory of multiple intelligences.

In the first part of the tasks, students read through the text with the help of INSERT technique which helps the development of intrapersonal intelligence. "INSERT means Interactive Noting System for Effective Reading and Thinking. Thus INSERT is an interactive noting procedure supporting metacognitive processes, during which procedure students, when reading the texts, use symbols on the margin according to their own understanding and knowledge. The symbols used are as follows:

$\checkmark \quad$ what I read corresponds with my preliminary knowledge and assumptions

what I read contradicts with my preliminary knowledge and assumptions, - $\quad$ and differs from those

$+\quad$ what I read contains new information for me

? what I read encourages me to do further research or ask questions

* additional information came to mind about what I read

INSERT is an effective method which enables students to follow their own understanding process during reading, to take into account other learning motivations, while their reading becomes an active, cognitive, and metacognitive process. If students follow their own understanding process, they actively contextualise information. With the help of this procedure the intense attention may be sustained all the while.”(Bárdossy, Dudás 2009:212)

I linked the areas of multiple intelligences to the cooperative technique of literary groups with a little modification. Although the technique better fits to Hungarian 
language and literature lesson, its basic concept can be used effectively in case of teaching other subjects as well. It is easy to link different types of tasks to each role, and these tasks strengthen one or the other areas of intelligence. When designing the lesson it is an essential aspect that students of teacher-training should get such knowledge which can be applied well in practice and which they can use immediately and transfer to pupils from lower school during their teaching practice.

Table 3

The development of intelligence areas with cooperative techniques

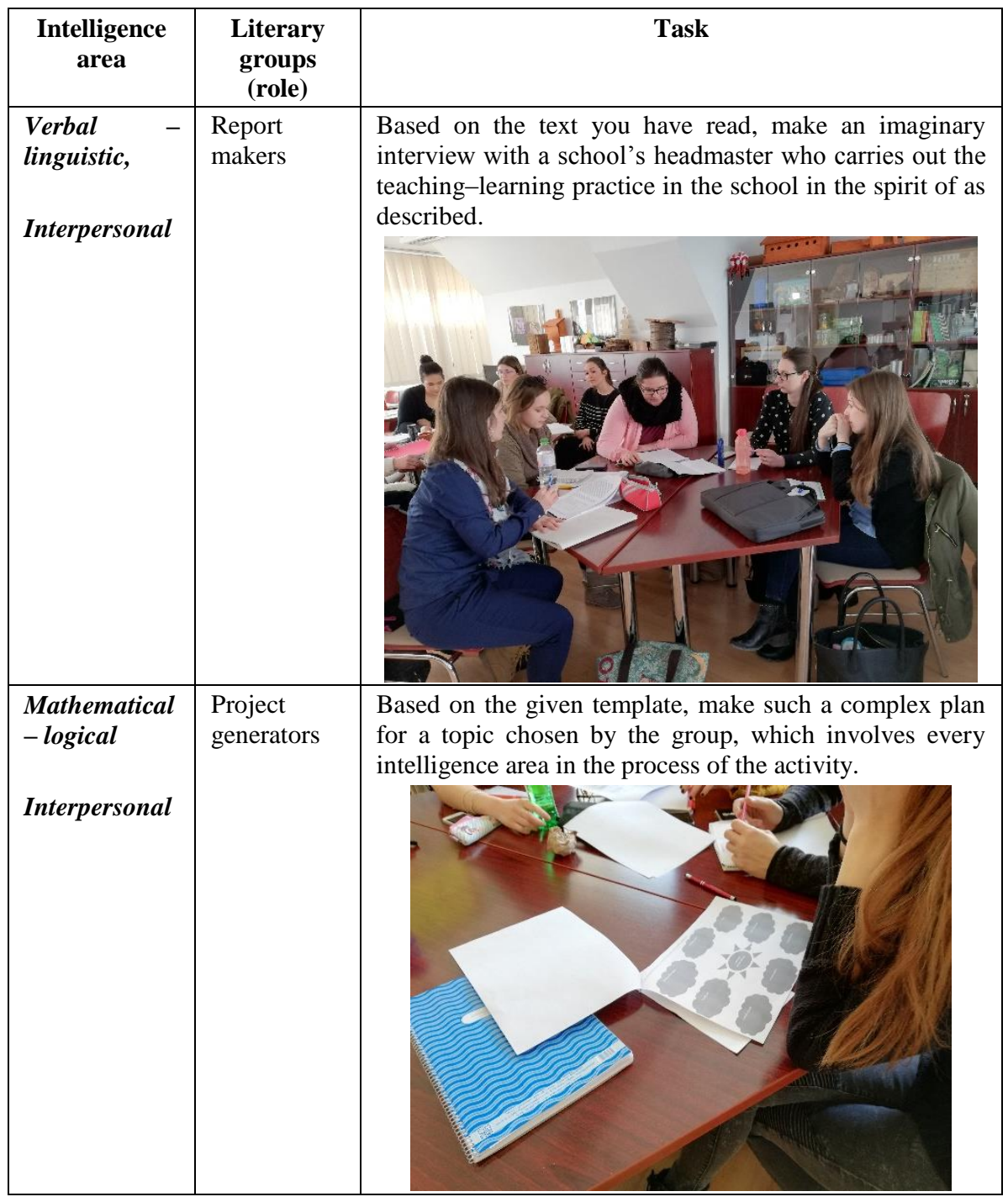




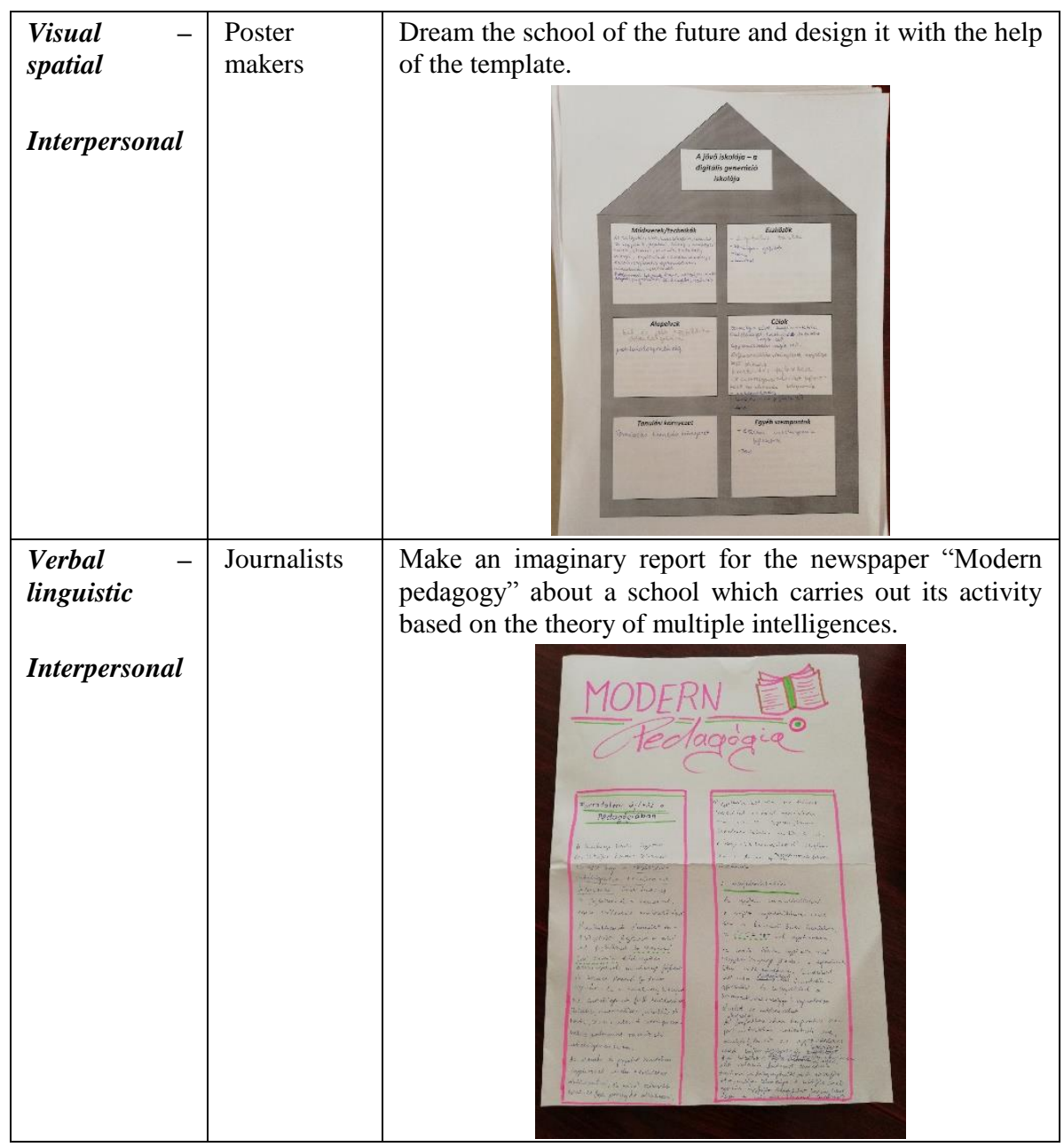

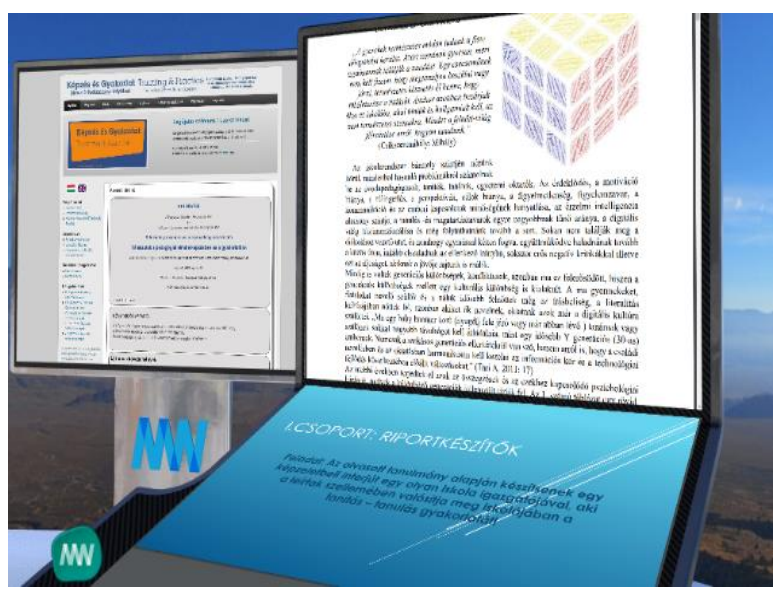

Figure 3
During the activity the students did not work only in the space, it was rather a help for them in the lesson. The templates, the teaching materials and the studies used in the lesson were displayed both in the classroom and in the space. (The program is not available for every student in the experimental process of curriculum

The "desk" of Group 1 with task description, study, and helping Internet source 
development.) I placed the group tasks in the four separate parts of the space. It is easily manageable for students, the work of the other groups is not disturbing in this way. However, having done the tasks there is an opportunity for reviewing each other's tasks and for bearing in the displayed sources and educational materials.

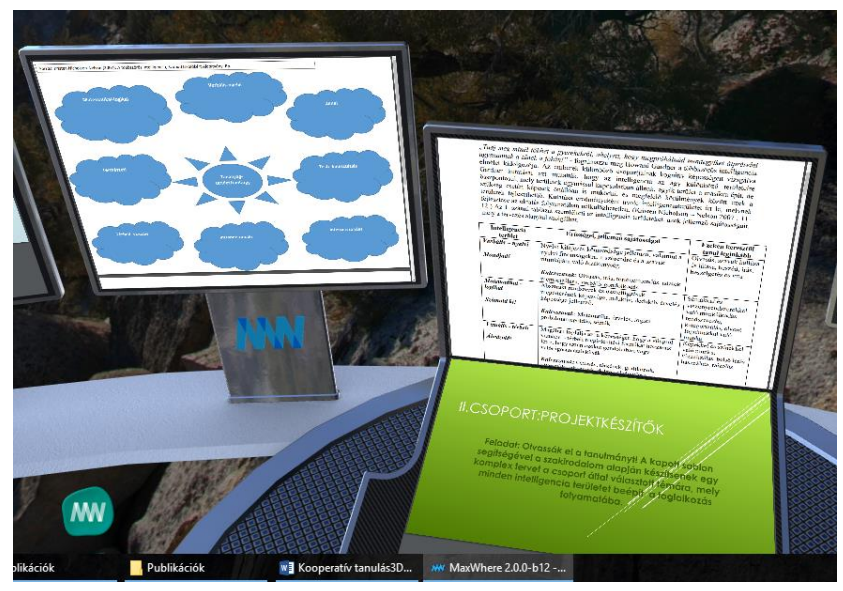

Figure 4

The "desk" of Group 2 with task description, helping template, and study

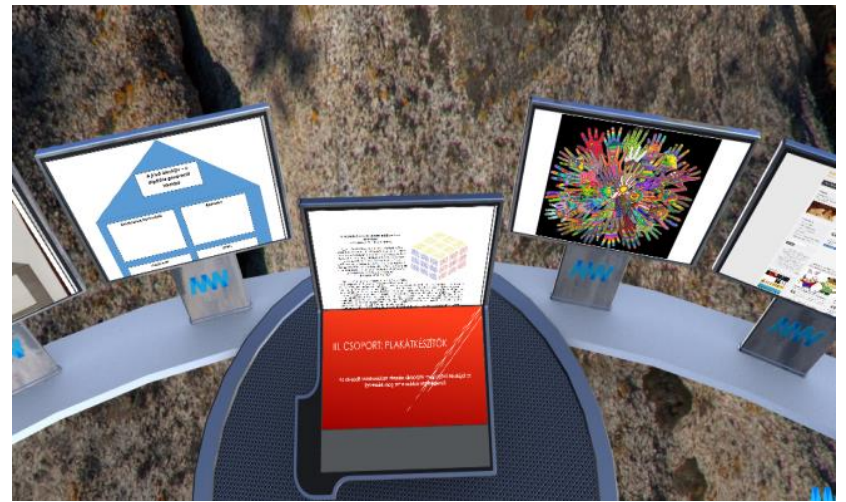

Figure 5

The "desk" of Group 3 with task description, helping template, and study 


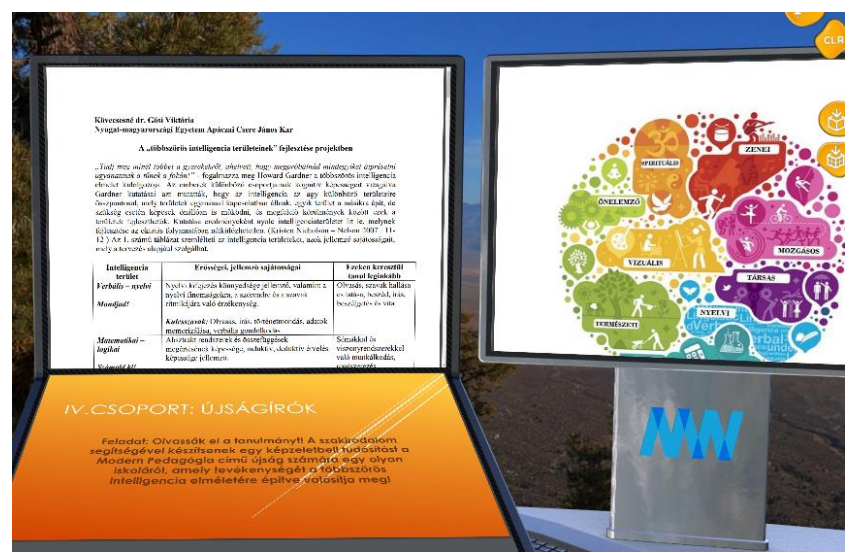

Figure 6

The "desk" of Group 4 with task description, helping template, and study

\section{Reflection}

"Literary groups" introduced the group tasks. After the demonstration of the groups I briefly summarised the experiences with the help of PowerPoint slides. After that we evaluated the classroom activity with the help of self-assessment and team-assessment sheets:

Table 4

Self-assessment sheet

\begin{tabular}{|l|}
\hline Self-assessment sheet: \\
\hline What I really liked when solving tasks: \\
\hline What I would like to know more about related to the topic (questions arisen during \\
processing): \\
\hline What was a problem during the work: \\
\hline What I would do differently next time: \\
\hline My most decisive experience during my assignment was: \\
\hline What I bring with me to my teaching practices: \\
\hline
\end{tabular}


Table 5

Team-assessment sheet

(Lénárd-Rapos 2009:84)

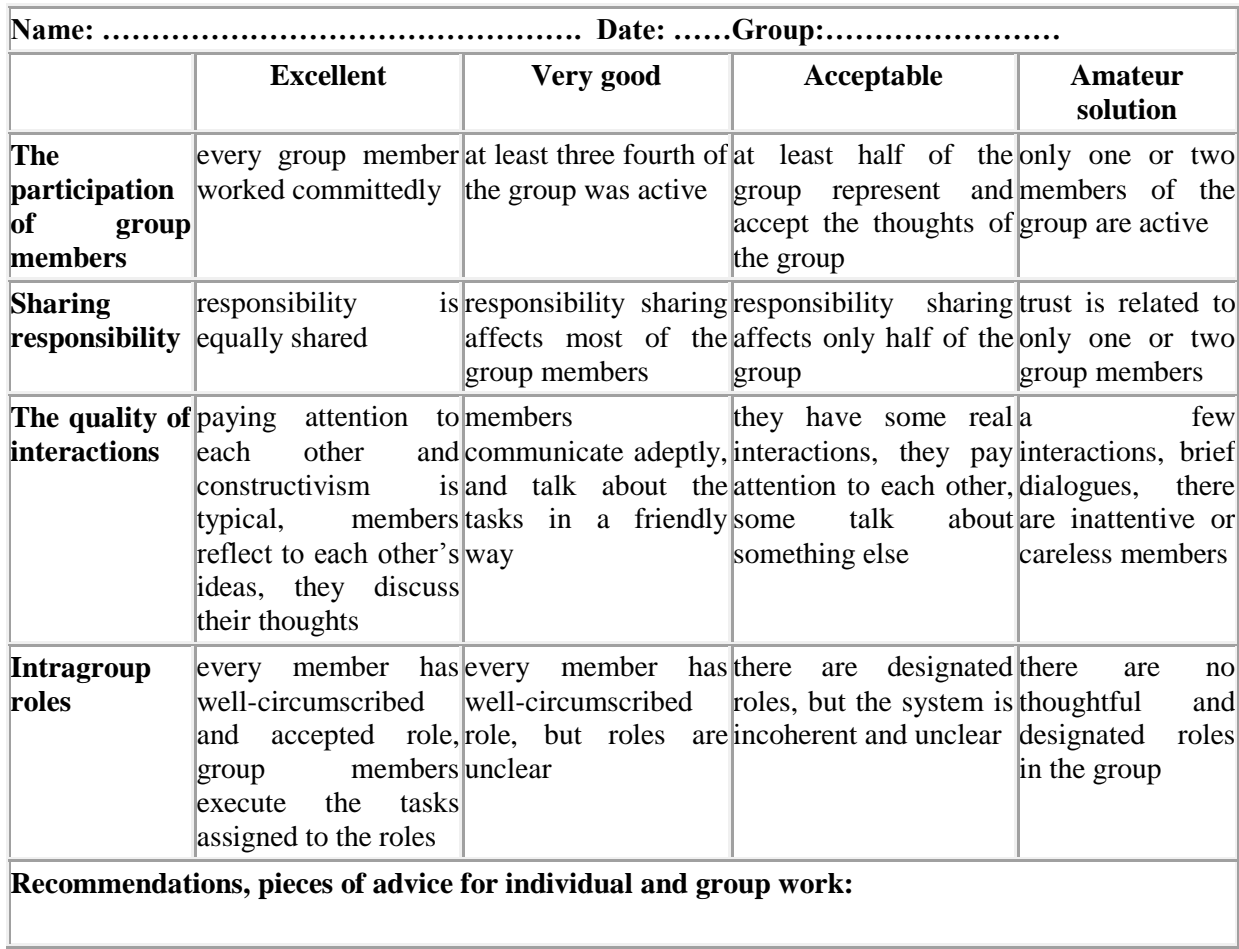

\section{Conclusions}

During my work I wanted to extend and expand my knowledge and experience gained through teaching cooperative learning, and to link them to a technology which fits to the world of the digital culture as well as to the habits and learning methods of primary and secondary school pupils, university students and young adults. Learning activity supported with VR space grabbed the attention of the students, and this new type of learning environment motivated them.

I definitely found it important that besides digital sources, some copies of studies and other teaching materials should be available for students for the group work in printed form in the lesson. The reason for this is that everybody has different learning styles with different habits, and besides some are visual type people. It is also important that motoric type young people who are used to noting and flipping through a book could also find the learning methods which are appropriate for them. However, it is a great help for the lecturer if the amount of photocopies decreases and the templates, forms, and task sheets used for cooperative learning techniques could be stored in a single place and in a form in which students can work and make the tasks, result available for others. 
A definite advantage is that the space enables the storage of curriculum, teaching materials and illustrative videos related to the topic in a single place, and for students it also facilitates obtaining credible information. It is not necessary to search for information for hours because the most important information and applications are constantly available. It may result in a more organised knowledge base and a result in a collection for the lecturer as well. I think that VR digital technology, which is built on classical teaching methods, highly develops the creativity and the digital competences of both the lecturer and the student.

\section{Acknowledgement}

My experiences showed that classical, classroom activities built on real cooperation could be effectively combined with learning opportunities provided by VR spaces since it enables more learning paths and with appropriate balance it may make the teaching-learning process more efficient. This work was supported by the FIEK program (Center for cooperation between higher education and the industries at the Széchenyi István University, GINOP-2.3.4-15-2016-00003)

\section{References}

[1] A tanulás tervezése és értékelése (Bárdossi Ildikó, Dudás Margit) Educatio Társadalmi Szolgáltató Nonprofit Kft., Bp. 2009

[2] A tanítás - tanulás hatékony szervezése (Alkotószerk.: Réthy Endréné) Educatio, Bp. 2008

[3] Bárdossy Ildikó - Dudás Margit - Pethőné Nagy Csilla - Priskinné Rizner Erika: A kritikai gondolkodás fejlesztése. Az interaktív és reflektív tanulás lehetőségei. Pécsi Tudományegyetem, Pécs - Budapest, 202, pp. 172-174

[4] Didaktika (szerk.: Falus Iván) Nemzeti Tankönyvkiadó, Bp. 2003

[5] Cseh Ágnes Gabriella: A tanulói értékelés széles körü értelmezése a gyakorlat számára, Taní-tani online folyóirat (http://www.tanitani.info/082_cseh)

[6] Dr. Gyarmathy Éva: Diszlexia a digitális korban, Müszaki Kiadó, Bp. 2012

[7] Hortobágyi Katalin: Projekt kézikönyv, Altern füzetek, Iskolafejlesztési Alapítvány OKI Iskolafejlesztési Központ Bp., 1991

[8] Kádár Annamária: Az érzelmi intelligencia fejlődése óvodás-és kisiskolás korban, Ábel Kiadó, Kolozsvár, 2012

[9] Kimmel Magdolna-Falu Iván: A portfólió fogalma, készítésének céljai és típusai In.: A tanítás-tanulás hatékony szervezése (szerk.: Réthy Endréné) Educatio, Bp. 2008 
[10] Kotschy Beáta: Kooperatív tanulás, In.: Pedagógiai lexikon II (szerk.:

Báthory Z. - Falus Iván) Keraban Kiadó, Bp. 1997

[10] Kovátsné Németh Mária: Fenntartható oktatás és projektpedagógia, In.: Új Pedagógiai Szemle, OKI, Bp. 2006

[11] Kováts-Németh Mária: Erdőpedagógiától a környezetpedagógiáig, Comenius Kft. Pécs, 2010

[13] Kristen Nicholson -Nelson: A többszörös intelligencia Scholastic, SZIA Bp., 2007

[14] Kövecsesné G. Viktória: A kooperatív tanulás szerepe, jelentősége az oktatási folyamatban, Katedra a szlovákiai magyar pedagógusok és szülök lapja, Katedra Alapítvány, Dunaszerdahely, 2016, 21-24

[15] Kövecsesné dr. Gősi Viktória: A digitális korszak oktatásmódszertani

kihívásai I., Katedra a szlovákiai magyar pedagógusok és szülők lapja, Katedra Alapítvány, Dunaszerdahely, Szlovákia XXV/7, ISSN 1335-6445, 2018, pp. 21-22

[16] Lénárd Sándor - Rapos Nóra: Fejlesztő értékelés. Gondolat, Budapest, 2009

[17] Lénárd Sándor - Rapos Nóra: MAGtár - Ötletek tanítóknak a fejlesztő értékeléshez és az adaptív tanulásszervezéshez OKI, BP. 2006

[18] M. Nádasi Mária: Adaptivitás az oktatásban, Comenius Bt. Pécs, 2001

[19] Németh András - Ehrenhard Skiera: Reformpedagógia és az iskola reformja, Nemzeti Tankönyvkiadó, Bp. 1999

[20] Óhidy Andrea: Az eredményes tanítási óra jellemzői - kooperatív tanulási formák a gyakorlatban In.: Új Pedagógiai Szemle, OKI Bp. 2011, www.upsz.hu (2011-03-13)

[21] Spencer Kagan: Kooperatív tanulás, Önkonet, Bp. 2001

[22] Tari Annamária: Y Generáció, Jaffa Kiadó, Bp. 2010

[23] Tari Annamária: Z Generáció, Tericum Kiadó, Bp. 2011 